\title{
A right-wing populist momentum? A review of 2017 elections across Europe
}

Article

Accepted Version

Halikiopoulou, D. (2018) A right-wing populist momentum? A review of 2017 elections across Europe. JCMS: Journal of Common Market Studies, 56 (S1). pp. 63-73. ISSN 1468-5965 doi: https://doi.org/10.1111/jcms.12769 Available at https://centaur.reading.ac.uk/77536/

It is advisable to refer to the publisher's version if you intend to cite from the work. See Guidance on citing.

To link to this article DOI: http://dx.doi.org/10.1111/jcms.12769

Publisher: Wiley

All outputs in CentAUR are protected by Intellectual Property Rights law, including copyright law. Copyright and IPR is retained by the creators or other copyright holders. Terms and conditions for use of this material are defined in the End User Agreement.

\section{www.reading.ac.uk/centaur}

\section{CentAUR}

Central Archive at the University of Reading

Reading's research outputs online 


\section{A right-wing populist momentum? A review of 2017 elections across Europe}

Daphne Halikiopoulou, University of Reading

d.halikiopoulou@reading.ac.uk

\section{Article published in the JCMS Annual review of the European Union, 2018 S1.}

\section{Introduction}

Right-wing populist parties competed in most electoral contests that took place in Europe in 2017, often as main contenders for power. Elections in France, the Netherlands, Austria, Germany and the Czech Republic were all characterised by an increase in the support for such parties. The French Front National (FN) progressed to the second round of the French Presidential election for the first time since 2002; the Austrian Freedom Party (FPÖ) gained access to office after forming a governing coalition with the centre-right People's Party (OVP); and the Alternative for Germany (AfD) entered parliament for the first time after substantially increasing its vote share from the previous legislative election of 2013. These results attracted extensive media attention, generating talk of a 'populist revolution' which is seen as part of a continuing trend that follows the 2014 European Parliament (EP) elections, Brexit and the election of Donald Trump; and they have coincided with increasing scholarly attention on the rise of right-wing populism in Europe and the US, with numerous accounts on both demand and supply-side dynamics driving this phenomenon (e.g. Inglehart and Norris, 2016; Rooduijn, 2014; Bonikowski, 2017; Aslanidis, 2016; Gidron and Bonikowski, 2013).

This article reviews the results of electoral contests that took place in 2017 in France, Norway, Bulgaria, the UK, the Netherlands, Austria, Germany and the Czech Republic, and examines them in comparative perspective. A detailed analysis, which takes into account important variations both across countries and across time, indicates that the results are not straightforward. Specifically, by focusing on these variations this article argues that: (1) Right-wing populism is not a uniform phenomenon. What we term 'right-wing populist' parties are in fact a range of parties that differ fundamentally in terms of their rhetoric and programmatic agendas; (2) the rise of parties that we now label 'right-wing populist' is not a new phenomenon. The 2017 election results can- and shouldbe interpreted as part of a broader trend that commenced in the mid 1980s with the rise of parties whose electoral fortunes have been fluctuating since. Indeed, niche parties which cut across traditional partisan alignments, such as those we term right-wing populist parties, have been contesting elections in Europe for 
the past 30 years, often successfully, including the FPÖ, List Pim Fortuyn (LPF) and the PVV, and the FN. Support has tended to vary across time, country and election type; (3) While not new, this phenomenon does pose new challenges. These are linked to supply-side, rather than demand-side, dynamics. In most Western European countries, the parties that are increasingly enjoying the most success are those that are attempting to distance themselves from fascism, 'speak' the language of democracy, and stress 'liberal values' to justify their exclusionary agendas (Halikiopoulou et al., 2013). This makes them more able to permeate mainstream ground and influence the policy agenda; and (4) the results from Eastern Europe are more mixed. On the one hand the overall pattern there is one of 'authoritarianism, territorial revisionism and the threat from territorial minorities' (Muis and Immerzeel, 2017). However, the 2017 elections in Bulgaria and the Czech Republic again show interesting variations with steady decline in support for ATAKA in the former and the rise of the civic Freedom and Direct Democracy (SPD) in the latter.

\section{Right-wing populism: A uniform phenomenon?}

First, it is important to place the results of 2017 within a broader theoretical framework. Since the 2014 'earthquake' EP elections (Halikiopoulou and Vasilopoulou, 2014), the electoral fortunes of parties that advocate immigration restrictions on the basis of a narrative that stresses popular sovereignty and anti-elitism have increasingly attracted academic interest. Such parties include a number of those that competed in the various 2017 elections such as the FN, the PVV, UKIP and the AfD; and others such as the Greek Golden Dawn (GD), the Danish People's Party (DF), the Swedish Democrats (SD) and the True Finns. While terminology varies, ranging from 'radical right' (Immerzeel et al., 2015), 'far right' (Halikiopoulou and Vlandas, 2016) and 'extreme right' (Arzheimer, 2009), the term 'right-wing populism' or 'populist radical right' is increasingly employed to describe these parties (e.g. Muis and Immerzeel, 2017; Rooduijn, 2017). The focus is on two central features that the parties share: an emphasis on popular sovereignty and an emphasis on national sovereignty; or in other words, populism and nationalism. First, populism is a form of 'democratic illiberalism' (Pappas, 2016), which posits that politics should always reflect the general will of the people (Mudde, 2004). What makes these parties populist is their shared emphasis on the 'people', and more specifically their description of society as shaped by the antagonistic relationship between 'us' the pure people and 'them' the corrupt elites (Mudde, 2004). Second, nationalism is a vision of society that prioritises the unity, autonomy and identity of the nation (Breuilly, 2005), focusing on a sharp division between in- groups and out-groups. What makes these parties nationalist is their shared focus on national homogeneity, sovereignty, and the espousal of anti-immigration policies resting on the principle of the national preference - or in other words, that access to the 
collective goods of the state should be confined to native groups (Halikiopoulou and Vlandas, 2016).

However, the categorisation of these parties as right-wing populist is to a degree problematic. The danger is that we may be lumping very different phenomena within the same category. While an anti-elite rhetoric and immigration scepticism are common among many of these parties, much more divides them, including their degree of extremism, the extent to which they adopt violence, their relationship with fascism, their position on social issues and state intervention of the economy as well as their voting base (Halikiopoulou and Vlandas, 2016). In other words, parties that we categorise as belonging to the broad umbrella of 'right-wing populism' might actually differ in kind rather than just degree. They have different ideological backgrounds, a different voting base and are often elected on very different platforms.

This is not simply a theoretical problem, but rather it affects the validity of our assessments of why these parties are increasing their electoral support. If they indeed differ in kind, then their rise cannot be traceable to a single cause (Pappas, 2016). For example, parties such as the Dutch PVV, the Bulgarian ATAKA and the Greek Golden Dawn differ fundamentally from each other and are elected on different platforms. While, therefore, it is important to identify trends and patterns, we can only do so if we can first ensure comparability. It is also important to disaggregate between the populist and nationalist attributes of these parties: i.e. to identify whether they are appealing because of their populism or because of their nationalism.

\section{A right-wing populist momentum? Variations in electoral support across country, time and election type}

Having identified potential theoretical and conceptual problems facing analyses on right-wing populism, this article proceeds to examine the 2017 election results in comparative perspective. Most right-wing populist parties that competed in the various electoral contests that took place across Europe in 2017 increased their support. These include the FN, the PVV, the AfD, and the FPÖ. The Czech SPD, which ran for the first time, also achieved a good result. The FN competed in the second round of the Presidential election for the first time since 2002, receiving its highest ever percentage of $33.9 \%$ in that round. The PVV received $13.1 \%$ of the votes cast, increasing its representation by 5 seats. The FPÖ received $26 \%$ of the votes cast and formed a coalition government with the centre-right OVP. In Germany the AfD entered parliament with $12.6 \%$ of the votes cast and 94 seats. The party came third, managing to draw voters from all major parties. Finally, in the Czech Republic the newly formed SPD received $10.64 \%$ of the votes cast occupying 22 seats in the Czech parliament. 
On the other hand, in the UK, Bulgaria and Norway right-wing populist parties declined. In the UK, UKIP decreased its electoral support from 12.6\% in 2015 to 1.8\% in 2017. In Bulgaria, the Bulgarian Patriotic Front - a nationalist alliance between the National Front for the Salvation for Bulgaria, ATAKA and the National Movement (IMRO-BNM) - received 9.07\% of the votes cast in 2017 . This percentage is smaller compared to the 11.83-combined percentage that three parties received in 20141. In Norway, the Norwegian Progress Party also declined, but just marginally from $16.3 \%$ in 2013 to $15.2 \%$ in 2017 losing two seats. However, the loss was smaller than expected as Progress Party leaders feared that they would lose support from anti-establishment voters having entered government in 2013 (Aardal and Bergh 2018). The results are summarised in Table 1.

\section{---Table 1 about here---}

The snapshot of the 2017 results offered above indeed illustrates that the majority of right-wing populist parties that competed across Europe performed well. An examination of the performance of the same parties across time, however, indicates that this phenomenon is neither linear nor new. First, a look at the wider picture illustrates that indeed the events of 2017 can be interpreted as part of a broader trend that commenced in the mid 1980s. As Figure 1 illustrates, since then the electoral performance of such parties has fluctuated: there was a sharp increase from 1985 onwards, a peak in the late 1990s, a decline in the 2000s and an increase again after 2009.

---Figure 1 about here---

A turn to specific parties reveals a similar picture. With regards to the cases where there was an increase in electoral support during 2017 elections, the longer-term analysis shows that these increases are not unprecedented. In France, for example, FN performance has fluctuated significantly since the 1980s and has varied across election type. With regards to parliamentary elections since 1993: the highest percentage the party has received in the first round is $15.25 \%$ in 1997; the lowest is $4.9 \%$ in 2007 . In the second round, percentages are slightly lower in all years, the highest being $8.75 \%$ the party received in 2017.

\footnotetext{
1 This result includes ATAKA, which ran separately during the 2014 election and obtained $4.53 \%$ of the votes cast and 11 seats; and the Patriotic Front consisting of the remaining two parties, which obtained $7.3 \%$ of the votes cast and 19 seats.
} 
With regards to Presidential elections, since 1995 the party has progressed to the second round twice: in 2002 and in 2017. In round 1 the lowest percentage the party has received was $10.44 \%$ in 2007; and the highest was $21.3 \%$ in 2017. In the second round, the party received $17.79 \%$ of the votes cast in 2002 and $33.9 \%$ in 2017 . This is the highest percentage the party has received and it is notable that it was able to retain a fairly high percentage in the second round. However, this could be explained as a protest vote, as given the winner-takes-all nature of the election, supporters did not expect the FN to win.

---Figure 3 about here---

An examination of List Pim Fortuyn (LPF) and PVV performance in the Netherlands reveals similar fluctuations. The highest vote share of a right-wing populist party in the Netherlands since the early 2000s is 17\%, received in 2002 by the LPF. The lowest is the same party's 5.7\%, received in elections held during the following year. The PVV's highest percentage is $15.45 \%$, received in 2010. The party subsequently decreased its support in 2012 with $10.08 \%$, which it increased to $13.1 \%$ in 2017 . While an increase from the previous election, this figure is lower than the $2002 \mathrm{LPF}$ vote and its own 2010 vote.

---Figure 4 about here---

The FPÖ follows a similar pattern. Figure 5 traces the party's performance in legislative elections from 1990 to 2017. The party's electoral fortunes have fluctuated significantly across time. Its best performance was in 1999 when the party received $26.91 \%$ of the votes cast. It also fared well in 2017 with $26 \%$, in 1995 with 21.89\%, and in 2013 with 21.51\%. Its worst performance was in 2002 with $10.01 \%$ and in 2006 with $11.04 \%$. The party also entered a coalition government in 1999.

---Figure 5 about here---

The German AfD and the Czech SPD are relatively new parties, not allowing for cross-time comparisons similar to those carried out above. It is important to note, however, that the AfD increased its support significantly since the previous election held in 2013.

\section{Supply-side patterns: the 'new winning formula'?}

While this phenomenon is not necessarily new, the electoral fortunes of these parties do represent a new challenge with regards to their progressive entrenchment in their respective political systems. Parties are in many ways 
themselves independent variables, determining their own electoral fortunes (Mudde, 2010). A closer look at the parties themselves, their narratives and their programmatic agendas, points to interesting supply-side patterns. Both withincountry variations and variations across time reveal a similar trend: in their majority, the parties most likely to fare well electorally in Western Europe are those that have (at least seemingly) distanced themselves from fascism and racism in their programmatic agendas in favour of a narrative that stresses ideological rather than biological rationalisations of national belonging. While they are still nationalist, and offer 'nationalist solutions' to all socio-economic problems (Vasilopoulou and Halikiopoulou, 2015), they identify the out-group not on the basis of ascriptive and immutable criteria of national membership such as race and common descent, but rather on the basis of toleration, excluding those who do not share 'our' liberal values such as democracy, multiculturalism and the rule of law (Halikiopoulou et al., 2013).

I will briefly focus on two examples: the AfD and the FN. First, the German case is interesting as it allows us to make this observation by looking at within country variations. Two parties located on the far right of the political spectrum, which competed both in the 2013 and the 2017 elections include the AfD and the National Democratic Party of Germany (NDP). In both elections it was the AfD rather than the extreme right National Democratic Party of Germany (NDP) that appealed to voters. Indeed, the NDP has remained marginalised in the past decades never receiving more than 1.6 per cent (in the 2005 elections). The key difference is that while the NDP is nativist - or ethnic nationalist - the AfD draws on civic nationalism excluding on the basis of ideology rather than race.

---Figure 6 about here---

While there is a debate among scholars as to whether the AfD can be classified as a populist radical right party, it is 'indeed located at the far-right end of Germany's political spectrum because of its nationalism, its stance against state support for sexual diversity and gender mainstreaming, and its market liberalism' (Arzheimer, 2015, p.551). In its 2013 manifesto, the AfD put forward a 'soft' Euroscepticism opposing the currency union and all bailouts, but showing a commitment to the European project itself. In terms of immigration, the party 'appeared to subscribe to the principles of free movement and free choice of residence for all EU citizens, although it wants to limit benefits (of which the party is critical in general) to long-term residents and their offspring' (Arzheimer, 2015, p. 546). The AfD, therefore, is not a straightforward case of 'nativism' (Arzheimer, 2015). The party is however, nationalist as discussed above. Its 2017 electoral campaign makes this point clear indicating that the party adopts a civic form of nationalism: an opposition to Islam and Muslims, which the party portrays as a threat to democracy, tolerance and liberalism. 
While the AfD is not nativist because it doesn't exclude on the basis of ascriptive criteria, it is nationalist because it defines the out-group and justifies its exclusion on the basis of ideology.

Second, the French case is interesting because it allows us to make this observation across time. The FN has increased its electoral support substantially after Marine Le Pen took over the party's leadership from her father. Marine Le Pen has reached a broader electoral base that captures 'younger' votes (e.g. Stockemer and Amengay, 2015) and achieves a closing of the far-right gender gap in France (Mayer, 2015). What is distinctive about Marine Le Pen's leadership is her strategy of 'de-demonization' of the party and a 'softening of its rhetoric' (Mayer, 2015; Ivaldi, 2015). This process has included a shift of emphasis from préférence to priorité nationale in order to disassociate the party from the negative connotations of Jean-Marie Le Pen's rhetoric and create distance from the party's reputation for exclusionist discrimination (Alduy and Wahnich, 2015). There are similarities here with the AfD: an attempt to exclude the out-group on the basis of toleration: i.e. to exclude those who are 'intolerant of us' and don't like our way of life. This has resulted in a heavily anti-Muslim rhetoric also coinciding with the series of terrorist attacks in France in the past years.

We may place these two case studies within a broader European trend. Across Western Europe, right-wing populist parties are more likely to compete successfully with other actors in the system when they are better able to tailor their discourse so as to present themselves and their ideologies as the true authentic defenders of the nation's unique reputation for democracy, diversity and tolerance (Halikiopoulou et al., 2013). This new 'winning formula' utilizes a form of civic nationalism that mobilizes around ideology rather than race (Halikiopoulou et al., 2013). This also explains why these parties focus heavily on Muslims - regardless of their citizenship - by presenting them as a threat to democratic values and a terrorist risk. It is an important observation, which suggests that it is nationalism, rather than populism, that offers a successful strategy for attracting voters and justifying policies.

\section{Eastern Europe}

The Eastern European pattern is somewhat different to that of Western Europe as 'the historical legacies and idiosyncrasies of the post-communist context have played a prominent role in shaping these parties' ideology' (Pirro, 2014, p. 600). Lower levels of immigration, a particular type of political culture related to the communist experience and absence of civil society have entailed the success of mostly extreme right variants, for example Jobbik in Hungary and KotlebaPeople's Party Our Slovakia. Specifically, such parties in Eastern Europe endorse 
'clericalism and irredentism, adopt 'social national' economics, and focus specifically on ethnic minorities, corruption and the EU (Pirro, 2014, p. 604).

The electoral contests that took place in Bulgaria and the Czech Republic in 2017 should be examined within this broader context. In Bulgaria, ATAKA fits the Eastern European trajectory discussed above. The party portrays itself as a Bulgarian patriotic party. It aspires to unite the nation under the common creed of Christianity, adopts an irredentist rhetoric, appeals to economic nationalism calling for a stronger role of the state in the economy, and places extensive emphasis on the salient issue of ethnic minorities. The party also places extensive focus on corruption (Pirro, 2014). ATAKA has experienced steady decline, decreasing its support despite running as a part of a nationalist alliance with the National Front for the Salvation for Bulgaria and the National Movement (IMRO-BNM). The picture in the Czech Republic is different: the newly formed SPD mostly resembles the Western European anti-immigrant parties, focusing heavily on the anti-EU and 'Islamization' narrative.

\section{Conclusion}

The brief comparative analysis offered above has illustrated that what we term 'right-wing populism' is neither a uniform, new nor linear phenomenon. This does not mean that the electoral fortunes of parties that competed in the series of elections that took place in 2017, such as the FN, the PVV, the FPÖ and the AfD are unimportant. On the contrary: the FN's 33.9\% in the second round of the French presidential election is the highest percentage the party has ever received. The PVV and the FPÖ increased their support. The biggest winner of 2017 was perhaps the AfD which entered Parliament for the first time, defying theories suggesting that parties on the far-right end of the political spectrum have limited opportunities in countries such as Germany. These results do suggest that in many ways right-wing populist parties pose challenges both to their domestic political systems and Europe more broadly. However, in order to understand these challenges, it is important to focus on variations in right-wing populist support within countries, across countries and across time.

These variations point to the importance of supply-side dynamics: while social discontent is present in all societies, support for right-wing populism varies. In other words, while the multiple insecurities - including economic, cultural and personal - that drive voters open up opportunities for parties that operate in the fringes of the political system, these opportunities are not always utilised- or they are utilised by different types of parties. It is supply-side factors that determine which parties will seize them and when. 
Specifically, the persistence of this phenomenon, and the new challenges it poses are linked both to how these parties compete with other actors in the system and how they frame their programmatic agendas to become appealing to voters. The former is about party competition with both the centre-right and the centre-left and is addressed elsewhere in this annual review issue; the latter is the 'new winning formula' described above: i.e. the ability of these parties to justify their exclusionary policies on the basis of ideological rather than biological rationalisations of national belonging.

In other words, these parties - especially in Western Europe - have 'learned' and are better equipped to compete with other actors in the system by presenting themselves as legitimate to the electorate. The greatest challenge is these parties' ability to permeate mainstream ground. Accommodating such parties' antiimmigrant positions is not new. Anti-immigrant parties have indeed had a contagion effect on other parties' immigration policy positions since 1990 (Van Spagne, 2010). What is new- and became more apparent during the various electoral contests that took place in 2017 across Europe- is the extent to which this has intensified: the legitimation of accommodative strategies is making right-wing populist parties more effective in driving the policy agenda and setting the terms on which mainstream actors compete.

\section{References}

Aardal, B. and Bergh, J. (2018). 'The 2017 Norwegian election', West European Politics, DOI: 10.1080/01402382.2017.1415778

Alduy, C. and Wahnich, S. (2015). Marine Le Pen prise aux mots: Décrytpage du nouveau discours frontiste. (Paris: Seuil)

Armingeon, K, V. Wenger, F. Wiedemeier, C. Isler, L. Knöpfel, D. Weisstanner and S. Engler. (2017). Comparative Political Data Set 1960-2015. (Bern: Institute of Political Science, University of Berne.)

Arzheimer, K. (2009). 'Contextual Factors and the Extreme Right Vote in Western Europe, 1980-2002'. American Journal of Political Science, Vol. 53, No 2, pp. 259275. doi: 10.1111/j.1540-5907.2009.00369.x

Arzheimer, K. (2015). 'The AfD: Finally a Successful Right-Wing Populist Eurosceptic Party for Germany?', West European Politics, Vol 38, No 3, pp. 535556.

Aslanidis, P. (2016). 'Is Populism an Ideology? A Refutation and a New Perspective', Political Studies, Vol. 64, No 1, pp. 88-104. 
Bonikowski, B. (2017). 'Ethno-Nationalist Populism and the Mobilization of Collective Resentment'. The British Journal of Sociology, Vol. 68, No. 1, pp. 181213.

Breuilly, J. (2005). 'Dating the nation: How old is an old nation?' In A. Ichijo \& G. Uzelac (eds), When is the nation? Towards an understanding of theories of nationalism. (London: Routledge), pp.15-39.

Federal Returning officer. (2017) Bundestag election 2017. Available at «https://www.bundeswahlleiter.de/en/bundestagswahlen/2017.html» Accessed May 292018.

Gidron, N. and Bonikowski, B. (2013). 'Varieties of Populism: Literature Review and Research Agenda', Weatherhead Working Paper Series, No. 13-0004

Halikiopoulou D, Mock, S. and Vasilopoulou, S. (2013). 'The civic zeitgeist: nationalism and liberal values in the European radical right'. Nations and Nationalism, Vol. 19, No 1, pp. 107-127.

Halikiopoulou, D. and Vasilopoulou, S. (2014). 'Support for the Far Right in the 2014 European Parliament Elections: A Comparative Perspective'. The Political Quarterly, Vol. 85, No. 3, pp. 285-288.

Halikiopoulou, D. and Vlandas, T. (2016). 'Risks, costs and labour markets: explaining cross-national patterns of far-right party success in European Parliament elections'. Journal of Common Market Studies, Vol. 54, No. 3, pp.636655.

Immerzeel, T., Lubbers, M. and Coffé, H. (2015). 'Competing with the radical right: Distances between the European radical right and other parties on typical radical right issues'. Party Politics, Vol. 22, No 6, pp.823-834.

Inglehart, R. and Norris, P. (2016). 'Trump, Brexit, and the Rise of Populism: Economic Have-Nots and Cultural Backlash', Harvard Kennedy School Faculty Research Working Paper Series [accessed on 26/01/17]

Ivaldi, G. (2015). 'Towards the median economic crisis voter? The new leftist economic agenda of the Front National in France'. French Politics, Vol. 13, No 4, pp. 346-369.

Mayer, N. (2015). 'The closing of the radical right gender gap in France?' French Politics, Vol. 13, No. 4, pp. 391-414. 
Ministère de l'intérieur. (2018) Les résultats. Available at «http://www.interieur.gouv.fr/Elections/Les-resultats » Accessed May 292018

Mudde, C. (2004). 'The Populist Zeitgeist', Government and Opposition, Vol. 39, No. 4, pp. 542- 563.

Mudde, C. (2010). 'The Populist Radical Right: A Pathological Normalcy', West European Politics, Vol. 33, No. 6, pp. 1167-1186

Muis, J. and T. Immerzeel. (2017). 'Causes and consequences of the rise of populist radical right parties and movements in Europe', Current Sociology Vol. 65, No. 6, pp. $909-930$

Norwegian Centre for Research Data. (2018). European Election Database. Available at «http://eed.nsd.uib.no/webview/index.jsp?study=http://129.177.90.166:80/ob j/fStudy/ATEP2004_Display\&node=0\&mode $=$ cube\&v=2\&cube=http://129.177. 90.166:80/obj/fCube/ATEP2004_Display_C1\&top=yes» Accessed 29 May 2018.

Pappas, T. S. (2016). 'The spectre haunting Europe: Distinguishing liberal democracy's challengers'. Journal of Democracy, Vol. 27, No. 4, pp. 22-36.

Pirro, A. L. P. (2014). 'Populist Radical Right Parties in Central and Eastern Europe: The Different Context and Issues of the Prophets of the Patria', Government and Opposition, Vol. 49, No. 4, pp. 599-628.

Rooduijn, M. (2014), 'Vox populismus: a populist radical right attitude among the public?'. Nations and Nationalism. Vol. 20, No. 1, pp. 80-92.

Rooduijn, M. (2017). 'What unites the voter bases of populist parties? Comparing the electorates of 15 populist parties'. European Political Science Review, pp. 118. doi:10.1017/S1755773917000145

Stockemer, D. and Amengay, A. (2015). 'The voters of the FN under Jean-Marie Le Pen and Marine Le Pen: Continuity or change?' French Politics, Vol. 13, No. 4, pp.370-390. doi:10.1057/fp.2015.16

Van Spanje, J. (2010). 'Contagious parties: Anti-immigrant parties and their impact on other parties' immigration stances in contemporary Western Europe.' Party Politics, Vol. 16, No. 5, pp. 563-586. 
Vasilopoulou, S. and Halikiopoulou, D. (2015). The Golden Dawn's nationalist Solution: Explaining the Rise of the Far Right in Greece. (New York: Palgrave).

\section{Tables and Figures}

Table 1: Far right party performance in 2017 elections across Europe

\begin{tabular}{c|c|c|c|c|c|c|}
\hline Country & Party & $\begin{array}{c}\text { Votes Cast \% } \\
2017\end{array}$ & Seats 2017 & $\begin{array}{c}\text { Previous } \\
\text { Election year }\end{array}$ & $\begin{array}{c}\text { Votes cast \% } \\
\text { Previous } \\
\text { Election Year }\end{array}$ & $\begin{array}{c}\text { Seats Previous } \\
\text { Election Year }\end{array}$ \\
\hline
\end{tabular}

Legislative elections

\begin{tabular}{c|l|c|c|c|c|c|}
\hline Netherlands & PVV & 13.1 & 20 & 2012 & 10.08 & 15 \\
\hline Bulgaria & Patriotic Front ${ }^{1}$ & 9.07 & 27 & 2014 & $11.83^{2}$ & 30 \\
\hline France & FN & $\begin{array}{c}13.20 \text { Round } 1 \\
8.75 \text { Round }\end{array}$ & 8 & 2012 & $\begin{array}{c}13.26 \text { Round 1 } \\
3.7 \text { Round 2 }\end{array}$ & 2 \\
\hline UK & UKIP & 1.8 & 0 & 2015 & 12.6 & 1 \\
\hline Norway & Progress Party & 15.2 & 27 & 2013 & 16.3 & 29 \\
\hline Germany & AfD & 12.6 & 94 & 2013 & 4.7 & 0 \\
\hline Austria & FPÖ & 26.0 & 51 & 2013 & 20.51 & 40 \\
\hline Czech Republic & SPD & 10.64 & 22 & 2013 & - & - \\
\hline
\end{tabular}

Presidential elections

\begin{tabular}{|c|c|c|c|c|c|c|}
\hline France & FN & $\begin{array}{l}21.3 \text { Round 1 } \\
\text { 33.9 Round 2 }\end{array}$ & N/A & 2012 & $\begin{array}{c}\text { 17.9 Round 1 } \\
\text { N/A Round 2 }\end{array}$ & N/A \\
\hline
\end{tabular}

${ }^{1}$ A nationalist alliance between the National Front for the Salvation for Bulgaria, ATTAKA and the National Movement (IMR0-BNM).

2 This result includes ATTAKA, which ran separately during the 2014 election and obtained $4.53 \%$ of the votes cast and 11 seats; and the Patriotic Front, which obtained $7.3 \%$ of the votes cast and 19 seats. 
Figure 1: Average Far right vote 1960-2015

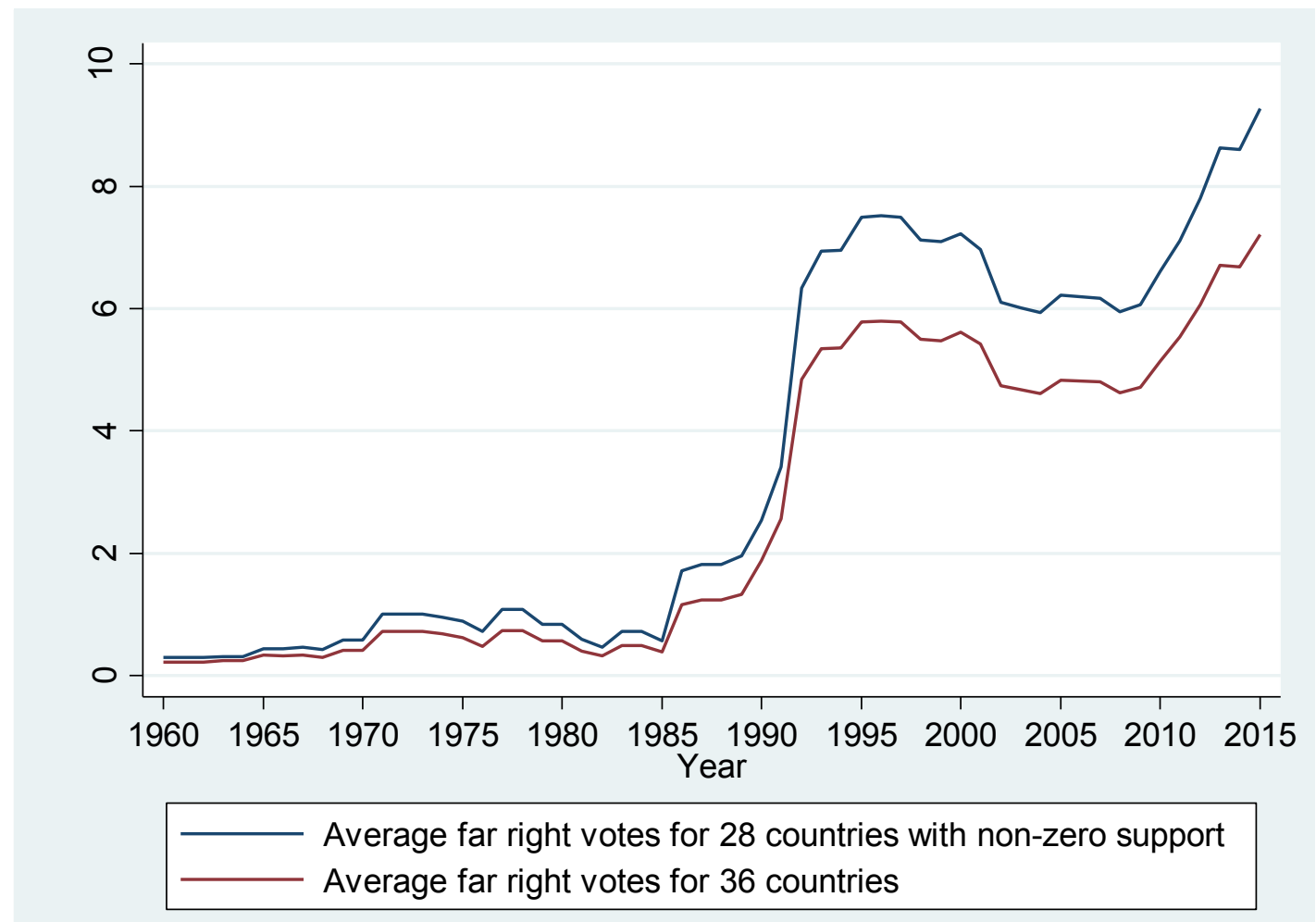

Source: Armingeon et al, 2017

Figure 2: FN Performance- French Legislative Elections 1993-2017 (\% Votes Cast)

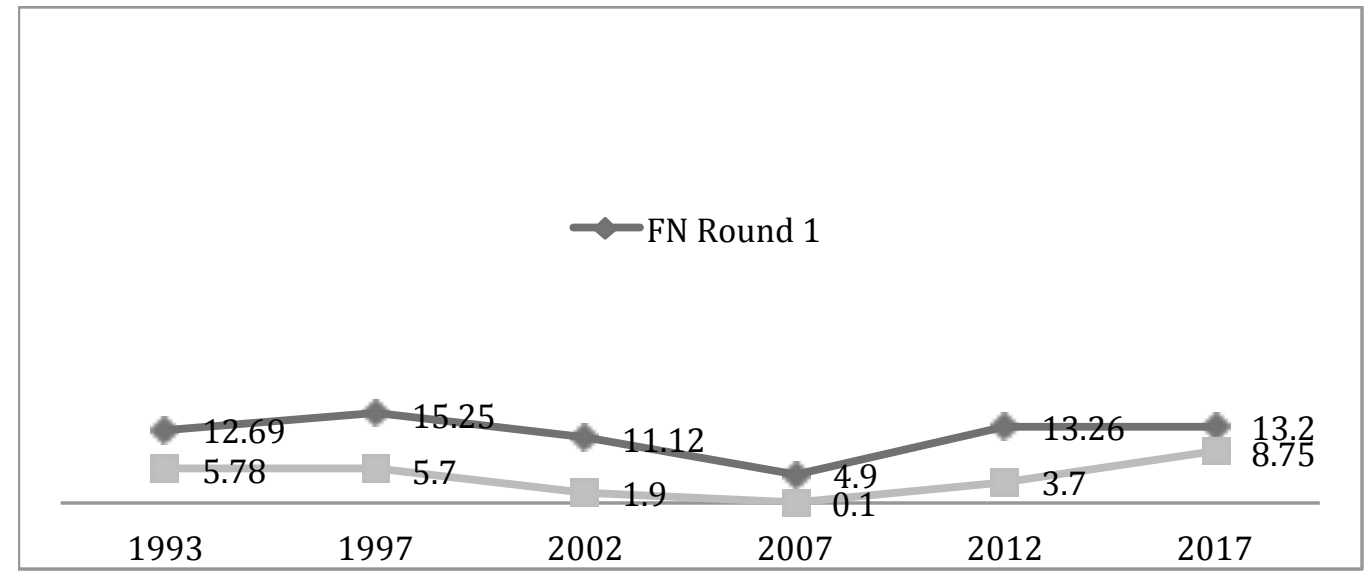

Source: Ministère de l'intérieur, 2018 
Figure 3: FN Performance- Presidential Elections 1995-2017

(\% Votes Cast)

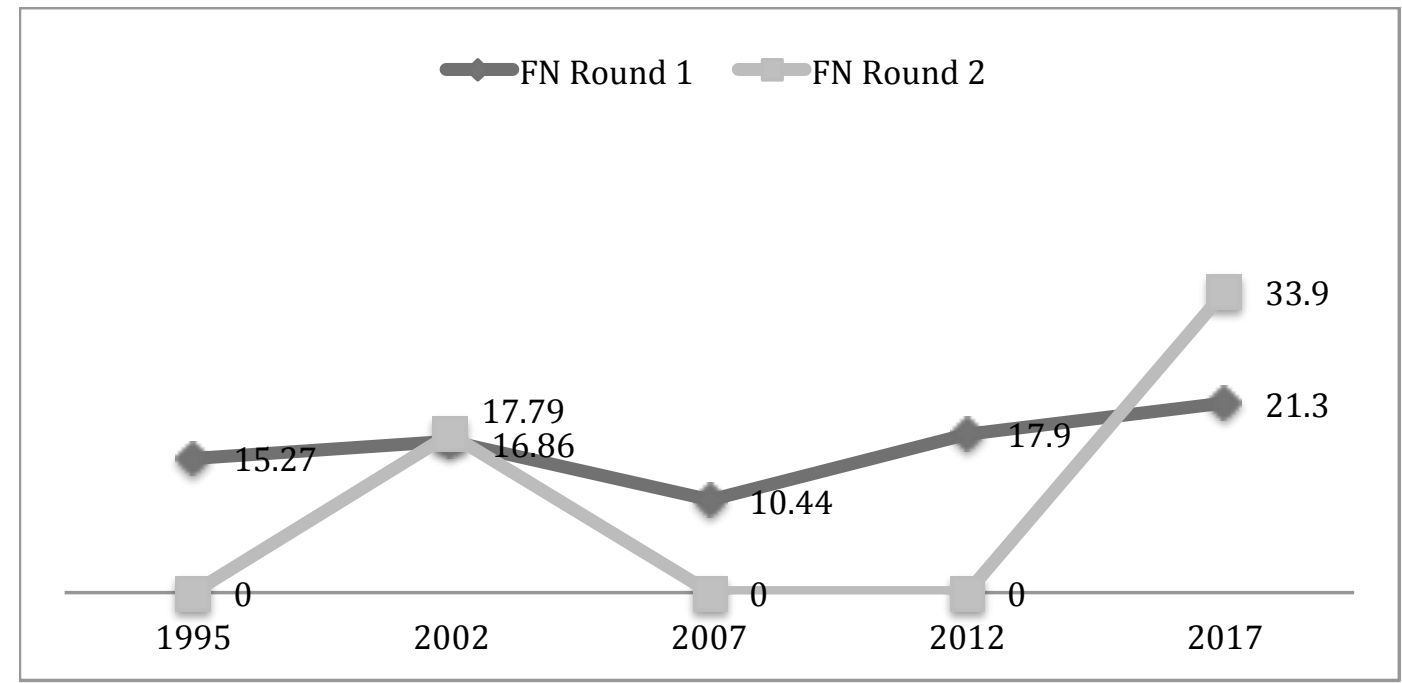

Source: Ministère de l'intérieur, 2018

Figure 4: Far right party performance (LPF and PVV) in Dutch legislative elections 2002-2017

(\% Votes cast)

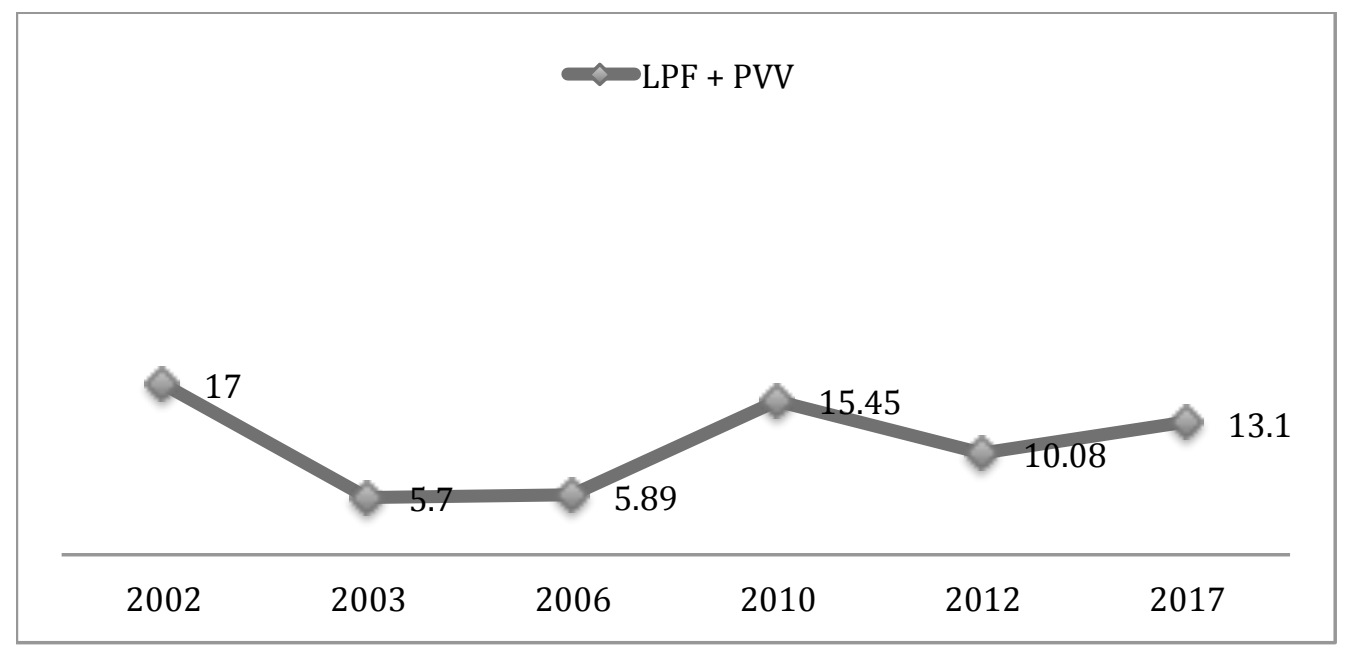

Source: European Election Database, 2018 
Figure 5: FPÖ Performance in Austrian Legislative Elections 1990-2017 (\% Votes Cast)

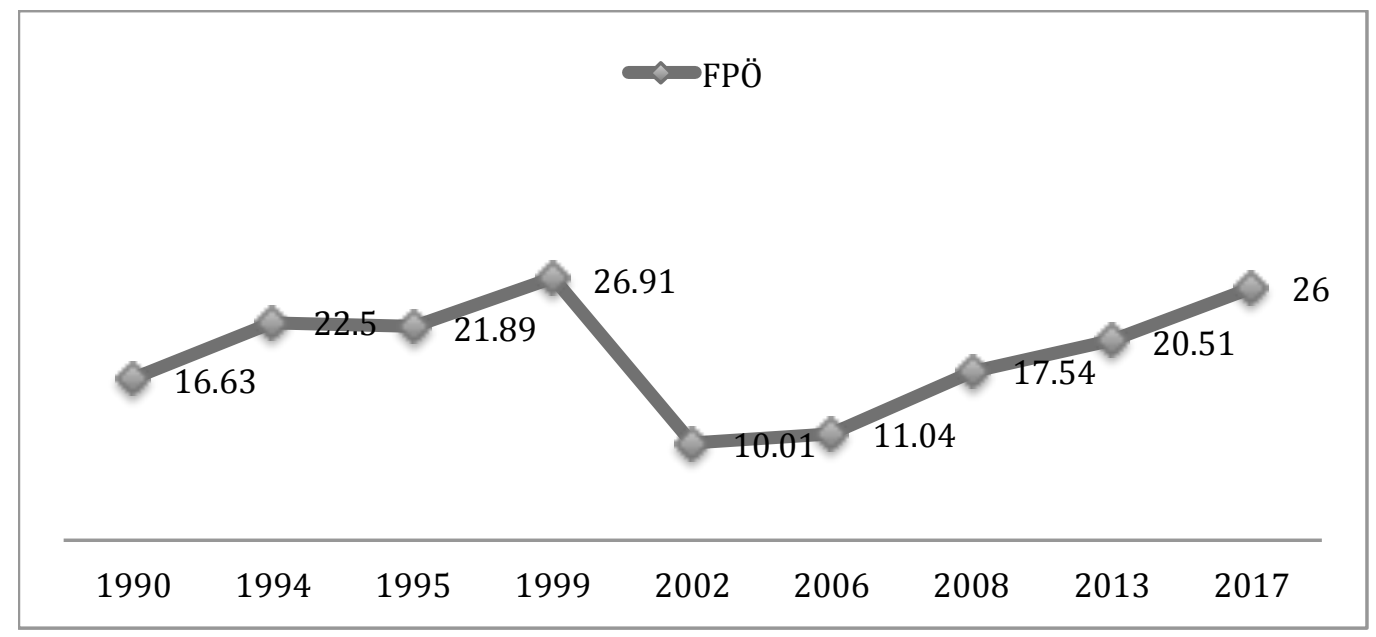

Source: European Election Database, 2018.

Figure 6: Far right party performance in legislative elections: Germany 1998-2017

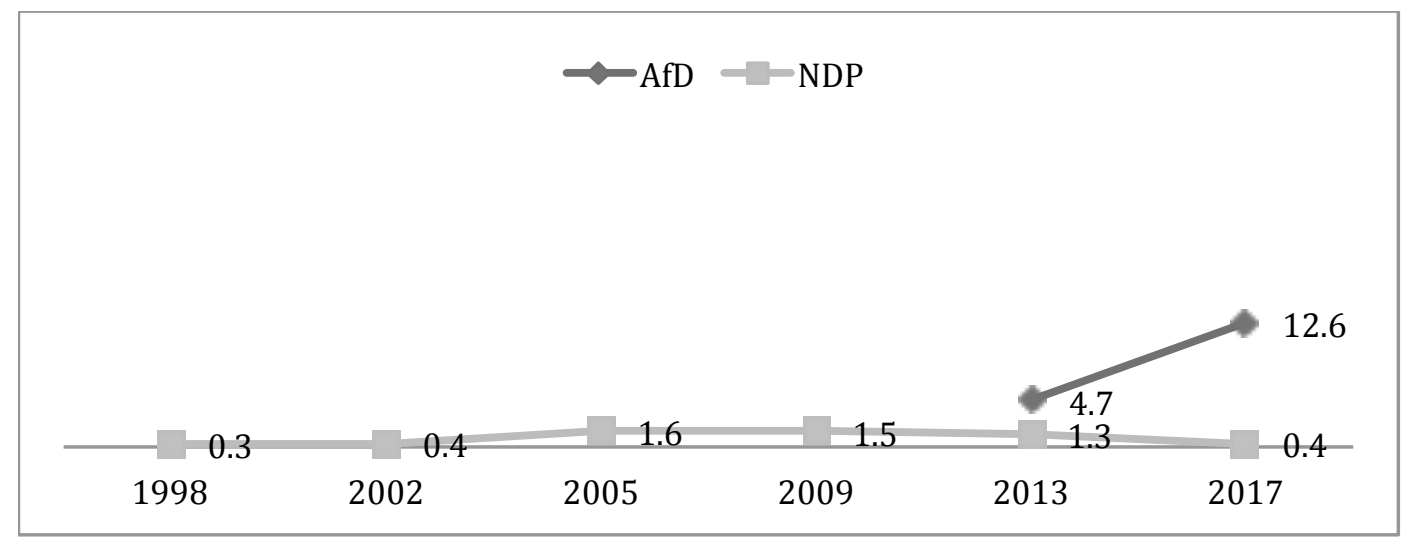

Source: The federal Returning officer, 2017. 